\title{
Effect of Nitrogen and Sulphur Levels on Growth and Yield of Quality Protein Maize (Zea mays.L)
}

\author{
Gopu Praveena* and Shikha Singh
}

Department of Agronomy, Sam Higginbottom University of Agriculture, Technology and Sciences, Prayagraj- 211007, Uttar Pradesh, India

*Corresponding author

\section{Keywords}

Quality Protein Maize, Nitrogen, Sulphur

Article Info

Accepted:

05 June 2020

Available Online:

10 July 2020

\begin{abstract}
A B S T R A C T
A field experiment was conducted during kharif 2019 at Central Crop Research Farm, Department of Agronomy, SHUATS, Prayagraj, (U.P.). The soil of experimental plot was sandy loam in texture, nearly neutral in soil reaction $(\mathrm{pH} 6.7)$, low in organic carbon $(0.35 \%)$, available $\mathrm{N}$ (230 kg/ha), available P (20 kg/ ha) and available K (189 kg /ha). The treatment consisted of 3 levels of Nitrogen viz. $\mathrm{N}_{1}(90 \mathrm{Kg} \mathrm{N} / \mathrm{ha}), \mathrm{N}_{2}(120 \mathrm{Kg} \mathrm{N} / \mathrm{ha}), \mathrm{N}_{3}(150$ $\mathrm{Kg} \mathrm{N} / \mathrm{ha}$ ) and 3 levels of Sulphur $\mathrm{S}_{1}(15 \mathrm{Kg} \mathrm{S} / \mathrm{ha}), \mathrm{S}_{2}(30 \mathrm{Kg} \mathrm{N} / \mathrm{ha}), \mathrm{S}_{3}(45 \mathrm{Kg} \mathrm{S} / \mathrm{ha})$.There were 9 treatments each replicated thrice. The experiment was laid out in Randomized Block Design. The result showed that growth parameters viz., plant height $(129.6 \mathrm{~cm})$ at 80 DAS, leaf area index (4.98) at $80 \mathrm{DAS}$, Dry weight (169.03 g/plant) at $80 \mathrm{DAS}$ and yield and yield attributes viz., No. of rows/cob (13.65), No. of seeds/row (30.65), 100-Grain Weight (20.90 g), Grain Yield (4.87 t/ha),Stover Yield (9 t/ha) and Harvest Index (35.11 $\%$ ) were recorded maximum in treatment $\mathrm{T}_{9}(150 \mathrm{Kg} \mathrm{N} / \mathrm{ha}+45 \mathrm{Kg} / \mathrm{ha})$. Hence the application of $150 \mathrm{Kg} \mathrm{N} / \mathrm{ha}$ along with $45 \mathrm{Kg} \mathrm{S} /$ ha gave the highest yield.
\end{abstract}

\section{Introduction}

Maize the American Indian word for corn means literally "that which sustains life". Maize is emerging as an important world cereal crop after wheat and rice, which is considered "Queen of Cereals", due to high productiveness, easy to process, low cost than others cereals (Jaliya et al., 2008).

The important goal for enchancing productivity of quality protein maize is to reduce the malnutrition through direct human consumption in tribal dominated area, where maize is a staple food. Nitrogen is a component of protein, nucleic acids and other compounds essential for plant growth process. Maize requires not only nitrogen, phosphorus or potassium but also sulphur (Kumar et al., 2015).

Sulphur, an essential for plant growth and development is considered a secondary nutrient because it is generally required in lower amounts than NPK (Jeet et al., 2014).The quality protein maize has widely adopted for cultivation in developing world to fight malnutrition. 


\section{Materials and Methods}

A field experiment was conducted during kharif 2019 at Central Crop Research Farm, Department of Agronomy, SHUATS, Allahabad, (U.P.). The soil of experimental plot was sandy loam in texture, nearly neutral in soil reaction $(\mathrm{pH}$ 6.7), low in organic carbon $(0.35 \%)$, medium in available $\mathrm{N}$ (219 $\mathrm{kg} / \mathrm{ha})$, high in available $\mathrm{P}(20 \mathrm{~kg} / \mathrm{ha})$ and low in available $\mathrm{K}(189 \mathrm{~kg} / \mathrm{ha})$. The treatment consisted of 3 levels of Nitrogen viz. $\mathrm{N}_{1}(90$ $\mathrm{Kg} \mathrm{N} / \mathrm{ha}), \mathrm{N}_{2}(120 \mathrm{Kg} \mathrm{N} / \mathrm{ha}), \mathrm{N}_{3}(150 \mathrm{Kg} \mathrm{N} / \mathrm{ha})$ and 3 levels of Sulphur $S_{1}(15 \mathrm{Kg} \mathrm{S} / \mathrm{ha}), S_{2}(30$ $\mathrm{Kg} \mathrm{N} / \mathrm{ha}), \mathrm{S}_{3}(45 \mathrm{Kg} \mathrm{S} / \mathrm{ha})$. There were 9 treatments each replicated thrice. The experiment was laid out in Randomized Block Design. It was sown on $25^{\text {th }}$ June 2019 with seed rate of $20 \mathrm{Kg} / \mathrm{ha}$ at spacing $50 * 20 \mathrm{cms}$. Phosphorus $(60 \mathrm{Kg} / \mathrm{ha})$ and Potassium (60 $\mathrm{Kg} / \mathrm{ha}$ ) are applied at basal and Nitrogen was applied in 2 splits (30 DAS and 60 DAS).

\section{Results and Discussion}

The growth parameters like plant height, leaf area index, chlorophyll and dry weight was significantly affected by the application of nitrogen and sulphur at different levels. Maize crop fertilized with $150 \mathrm{Kg} \mathrm{N} / \mathrm{ha}$ along with $45 \mathrm{Kg} \mathrm{S} / \mathrm{ha}$ significantly resulted in plant height $(129.6 \mathrm{~cm})$, Leaf area index (4.97) and dry weight (169.03 g/plant) at 80 DAS (Table.1). The nitrogen has beneficial effect on plant metabolism which effect physiological process of the crop and thereby increases the growth parameters (Jeet et al., 2014). Sulphur involve in synthesis of $S$ containing of amino acids viz. cysteine, cystene and methionine, various enzyamatic process resulting in greater meristimatic activities and apical growth thereby overall growth of the plant (Choudhary et al., 2013).

Yield and yield attributes were also significantly affected by nitrogen and sulphur at different levels. Maize crop fertilized with $150 \mathrm{Kg} \mathrm{N} / \mathrm{ha}$ along with $45 \mathrm{Kg} \mathrm{S} / \mathrm{ha}$ significantly resulted in rows/cob (13.65), Seeds/cob (30.65), Test weight (20.90 g), Grain yield (4.87 t/ha), Stover yield ( $9 \mathrm{t} / \mathrm{ha})$ and Harvest Index (35.11\%) (Table.2, 3).

This may be due to larger cob size, proper pollination, translocation of sugars and starch and finally proper grain set due to higher nitrogen fertilizer dose and high nitrogen use efficiency and sulphur provides better nutrition to reproductive parts being a qualitative nutrient. These findings are in conformity to recommendation of Alam et al., (2003).

Table.1 Effect of Nitrogen and Sulphur Levels on Growth Parameters of Quality Protein Maize (80 DAS)

\begin{tabular}{|c|c|c|c|}
\hline Treatments & Plant height $(\mathrm{Cm})$ & Leaf area index & Dry weight (g/plant) \\
\hline $90 \mathrm{Kg} \mathrm{N} / \mathrm{ha}+15 \mathrm{Kg} \mathrm{S} / \mathrm{ha}$ & 104.53 & 3.60 & 118.77 \\
\hline $90 \mathrm{Kg} \mathrm{N} / \mathrm{ha}+30 \mathrm{Kg} \mathrm{S} / \mathrm{ha}$ & 104.442 & 3.64 & 123.2 \\
\hline $90 \mathrm{Kg}$ N/ha $+45 \mathrm{Kg} \mathrm{S} / \mathrm{ha}$ & 111.41 & 3.73 & 134.77 \\
\hline $120 \mathrm{Kg} \mathrm{N} / \mathrm{ha}+15 \mathrm{Kg} \mathrm{S} / \mathrm{ha}$ & 111.53 & 4.06 & 132.6 \\
\hline $120 \mathrm{Kg} \mathrm{N} / \mathrm{ha}+30 \mathrm{Kg} \mathrm{S} / \mathrm{ha}$ & 103.06 & 4.08 & 138.67 \\
\hline $120 \mathrm{Kg} \mathrm{N} / \mathrm{ha}+45 \mathrm{Kg} \mathrm{S} / \mathrm{ha}$ & 119.86 & 4.72 & 157.67 \\
\hline $150 \mathrm{Kg} \mathrm{N} / \mathrm{ha}+15 \mathrm{Kg} \mathrm{S} / \mathrm{ha}$ & 118.32 & 4.70 & 152.03 \\
\hline $150 \mathrm{Kg} \mathrm{N} / \mathrm{ha}+30 \mathrm{Kg} \mathrm{S} / \mathrm{ha}$ & 116.78 & 4.66 & 159.9 \\
\hline $150 \mathrm{Kg} \mathrm{N} / \mathrm{ha}+45 \mathrm{Kg} \mathrm{S} / \mathrm{ha}$ & 129.6 & 4.97 & 169.03 \\
\hline $\operatorname{SEm}( \pm)$ & 4.01 & 0.03 & 3.93 \\
\hline $\mathrm{CD}(\mathrm{P}=\mathbf{0 . 0 5})$ & 12.0 & 0.09 & 11.78 \\
\hline
\end{tabular}


Table.2 Effect of Nitrogen and Sulphur Levels on Yield Attributes and yield

\begin{tabular}{|c|c|c|c|c|c|c|}
\hline Treatments & $\begin{array}{c}\text { Rows/cob } \\
\text { (No.) }\end{array}$ & $\begin{array}{l}\text { Seeds/row } \\
\text { (No.) }\end{array}$ & $\begin{array}{c}\text { Test } \\
\text { weight } \\
\text { (g) }\end{array}$ & $\begin{array}{c}\text { Grain } \\
\text { yield } \\
\text { (t/ha) }\end{array}$ & $\begin{array}{l}\text { Stover } \\
\text { Yield } \\
\text { (t/ha) }\end{array}$ & $\begin{array}{c}\text { Harvest } \\
\text { index } \\
(\%)\end{array}$ \\
\hline $90 \mathrm{Kg} \mathrm{N} / \mathrm{ha}+15 \mathrm{Kg} \mathrm{S} / \mathrm{ha}$ & 10.32 & 19.30 & 16.57 & 1.87 & 5.00 & 27.66 \\
\hline $90 \mathrm{Kg}$ N/ha + $30 \mathrm{Kg} \mathrm{S} / \mathrm{ha}$ & 10.30 & 19.95 & 17.10 & 2.66 & 6.00 & 31.22 \\
\hline $90 \mathrm{Kg} \mathrm{N} / \mathrm{ha}+45 \mathrm{Kg} \mathrm{S} / \mathrm{ha}$ & 11.53 & 23.53 & 18.10 & 3.77 & 7.13 & 33.66 \\
\hline $120 \mathrm{Kg} \mathrm{N} / \mathrm{ha}+15 \mathrm{Kg} \mathrm{S} / \mathrm{ha}$ & 10.95 & 22.04 & 17.78 & 3.39 & 7.00 & 32.63 \\
\hline $120 \mathrm{Kg} \mathrm{N} / \mathrm{ha}+30 \mathrm{Kg} \mathrm{S} / \mathrm{ha}$ & 11.63 & 24.43 & 18.15 & 3.58 & 7.40 & 32.65 \\
\hline $120 \mathrm{Kg} \mathrm{N} / \mathrm{ha}+45 \mathrm{Kg} \mathrm{S} / \mathrm{ha}$ & 12.55 & 28.87 & 18.93 & 4.18 & 8.00 & 34.38 \\
\hline $150 \mathrm{Kg} \mathrm{N} / \mathrm{ha}+15 \mathrm{Kg} \mathrm{S} / \mathrm{ha}$ & 11.95 & 26.73 & 18.60 & 4.05 & 8.25 & 32.73 \\
\hline $150 \mathrm{Kg} \mathrm{N} / \mathrm{ha}+30 \mathrm{Kg} \mathrm{S} / \mathrm{ha}$ & 12.27 & 27.93 & 18.63 & 4.04 & 7.73 & 34.51 \\
\hline $150 \mathrm{Kg} \mathrm{N} / \mathrm{ha}+45 \mathrm{Kg} \mathrm{S} / \mathrm{ha}$ & 13.65 & 30.65 & 20.90 & 4.87 & 9.00 & 35.11 \\
\hline $\operatorname{SEm}( \pm)$ & 0.25 & 0.55 & 0.23 & 0.10 & 0.42 & 2.07 \\
\hline $\mathrm{CD}(\mathrm{P}=\mathbf{0 . 0 5})$ & 0.76 & 1.66 & 0.7 & 0.33 & 1.27 & 6.22 \\
\hline
\end{tabular}

Table.3 Effect of Nitrogen and Sulphur on Economics of Quality Protein Maize

\begin{tabular}{|c|c|c|c|c|}
\hline Treatments & $\begin{array}{c}\text { Cost of } \\
\text { cultivation }(₹ / h a)\end{array}$ & $\begin{array}{l}\text { Gross Returns } \\
\text { (₹ /ha) }\end{array}$ & $\begin{array}{l}\text { Net Returns } \\
\text { (₹/ha) }\end{array}$ & B:C Ratio \\
\hline $90 \mathrm{Kg} \mathrm{N} / \mathrm{ha}+15 \mathrm{Kg} \mathrm{S} / \mathrm{ha}$ & 50815 & 87400 & 36585 & 0.72 \\
\hline $90 \mathrm{Kg} \mathrm{N} / \mathrm{ha}+30 \mathrm{Kg} \mathrm{S} / \mathrm{ha}$ & 55,825 & 113200 & 57375 & 1.03 \\
\hline $90 \mathrm{Kg} \mathrm{N} / \mathrm{ha}+45 \mathrm{Kg} \mathrm{S} / \mathrm{ha}$ & 60,835 & 146700 & 85865 & 1.41 \\
\hline $120 \mathrm{Kg} \mathrm{N} / \mathrm{ha}+15 \mathrm{Kg} \mathrm{S} / \mathrm{ha}$ & 51244 & 137800 & 86556 & 1.69 \\
\hline $120 \mathrm{Kg} \mathrm{N} / \mathrm{ha}+30 \mathrm{Kg} \mathrm{S} / \mathrm{ha}$ & 56254 & 145600 & 89346 & 1.59 \\
\hline $120 \mathrm{Kg} \mathrm{N} / \mathrm{ha}+45 \mathrm{Kg} \mathrm{S} / \mathrm{ha}$ & 61264 & 163600 & 102336 & 1.67 \\
\hline $150 \mathrm{Kg} \mathrm{N} / \mathrm{ha}+15 \mathrm{Kg} \mathrm{S} / \mathrm{ha}$ & 51667.8 & 163500 & 111832.2 & 2.16 \\
\hline $150 \mathrm{Kg} \mathrm{N} / \mathrm{ha}+30 \mathrm{Kg} \mathrm{S} / \mathrm{ha}$ & 56677 & 158100 & 101423 & 1.78 \\
\hline $150 \mathrm{Kg} \mathrm{N} / \mathrm{ha}+45 \mathrm{Kg} \mathrm{S} / \mathrm{ha}$ & 61687 & 187400 & 125713 & 2.04 \\
\hline
\end{tabular}

The highest gross (Rs 18,7400) and net returns (Rs 12,5713) were obtained in $\mathrm{T}_{9}(150$ $\mathrm{kg} \mathrm{N} / \mathrm{ha}+45 \mathrm{~kg} \mathrm{~S} / \mathrm{ha}$ ) and $\mathrm{B}: \mathrm{C}$ ratio was highest in $\mathrm{T}_{7} 150 \mathrm{~kg} \mathrm{~N} / \mathrm{ha}+30 \mathrm{~kg} \mathrm{~S} / \mathrm{ha}$ (2.16). The combined application of nitrogen and sulphur increases the grain yield, stover yield and quality of maize which ultimately increases the gross and net returns. These result were in line with results of (Jeet et al., 2012).

On the basis of one year experiment, application of $150 \mathrm{~kg} \mathrm{~N} / \mathrm{ha}$ along with $45 \mathrm{~kg}$ $\mathrm{S} / \mathrm{ha}$ is more productive whereas $150 \mathrm{~kg} \mathrm{~N} / \mathrm{ha}$ $+30 \mathrm{~kg} \mathrm{~S} /$ ha was economically effective.

\section{Acknowledgement}

I express gratitude to my advisor Dr. Shikha Singh for constant support and guidance. I am indebted to Prof. (Dr.) Thomas Abharam and Prof. (Dr.) Joy Dawson and all the faculty members of SHUATS for inspiration.

\section{References}

Alam, Mh, Morshed., Islam, Md, Nazrul., Shah, Md., Rahmam, M. and Howue, M. 2003. Effects of sulphur and nitrogen on the yield and seed quality of maize. Online journal of biological 
sciences. 3(7): 643-654, ISSN 16084217.

Chaudhary, R., Singh, D. and Nepalia, V.2013. Productivity and economics of quality protein maize (Zea mays) as infssluenced by nitrogen levels, its scheduling and sulphur application. Indian Journal of Agronomy. 58(3): 340-343.

Jaliya, M.M., Falaki, A.M, Mahmud, M., Abubakar, I.U and Sani, Y.A. 2008. Response of QPM to sowing date and NPK fertilizer rate on yield and yield components of QPM. Savannah journal of agriculture. 3:24-35.

Jeet, S., Singh, J.P., Kumar, R. and Om, H. 2014.Response of nitrogen and sulphur levels on productivity of QPM hybrid (Zea mays) under dryland conditions of eastern uttar pradesh. Indian Journal of Agricultural Sciences. 84 (5): 585-94.

Jena, N., Vani, K.P., Rao, V.P. and Sankar, A.S. 2015. Effect of Nitrogen and Phosphorus Fertilizers on Growth and Yield of Quality Protein Maize. International Journal of Science and Research.4(12): 197-200.

Kumar, B., Singh, G., Rajesh, K. and Kumar, K. 2015.Effect of nitrogen and sulphur nutrition on growth and yield of maize genotypes under eastern plain zone of U.P. International Journal of Agricultural Sciences. 12(2):181-185.

Navtha, V., Vani, K.P., Surendra Babu, P. and Srinivas, A. 2017. Response of growth of Quality Protein Maize as influenced by sulphur levels and method of application. Int.J.Curr.Microboil.App. Sci. 6(2): 1113-1122.

Prathyusha, C., Hemalatha, S., Sridhar, K. and Basava, S. 2013. Growth and productivity of speciality corn as influenced by different levels of nitrogen under Pongamia plantations. International Journal of Applied Biology and Pharmaceutical Technology 4 (4): 110-113.

Singh, A., Vyas, A.K and Singh, A.K. 2000. Effect of nitrogen and Zinc application on growth, yield and net returns of maize (Zea mays. L.). Annals of Agriculture Research.21:296-97.

Thirupathi, I., Suneetha, K.B. and Sharma, H.K.S. 2016.Effect of nitrogen and sulphur on growth, yield, quality and economics og single cross hybrid maize. International Journal of Science, Environment.5(5): 2989-98.

\section{How to cite this article:}

Gopu Praveena and Shikha Singh. 2020. Effect of Nitrogen and Sulphur Levels on Growth and Yield of Quality Protein Maize (Zea mays.L). Int.J.Curr.Microbiol.App.Sci. 9(07): 380-383. doi: https://doi.org/10.20546/ijcmas.2020.907.041 